\title{
Craniovertebral Junction Melanocytoma: A Case Report
}

\section{Kraniyovertebral Bileşke Melanositomu: Bir Olgu Sunumu}

Pranshu BHARGAVA, Sarvpreet Singh GREWAL, Yashbir DEWAN, Sukhdeep Singh JHAWAR, Vikas JAIN, Bharat GUPTA

Christian Medical College, Department of Neurosurgery, Ludbiana, India

Correspondence address: Pranshu BHARGAVA / E-mail: bhargava_pranshu@rediffmail.com

\begin{abstract}
Melanocytomas are rare melanocytic tumors of the central nervous system and its presence at the foramen magnum is extremely rare. We report a case of a 55-year-old male presenting with progressive quadriparesis over one year. Imaging showed a well-defined intradural extramedullary lobulated mass at craniovertebral junction towards the left side and extending to left C2-3 neural foramina. Patient was operated through foramen magnum approach with near total excision of tumor. On a ten-month follow up, he was ambulatory with normal motor power on right side of body and left lower limb and with motor power of 4-/5 in left upper limb. Histopathology and immunohistochemistry confirmed the lesion to be a melanocytoma.
\end{abstract}

KEYWORDS: Melanocytoma, Foramen magnum, Craniovertebral junction

öz

Melanositomlar merkez sinir sisteminin nadir melanositik tümörleridir ve foramen magnumda bulunmaları son derece nadirdir. Bir yıl boyunca ilerleyen kuadraparezili 55 yaşında bir erkek olguyu sunuyoruz. Görüntüleme kraniyovertebral bileşkede sol tarafta, sol C2-3 nöral foramenlere doğru uzanan iyi tanımlanmış bir intradural ekstramedüller lobule kitle gösterdi. Hasta foramen magnum yaklaşımıyla ameliyat edildi ve tümör hemen hemen tümüyle eksize edildi. On aylık takipte vücudun sağ tarafı ve sol alt uzuvda normal motor güç ve sol üst uzuvda 4-/5 motor güçle hareket edebilir hale geldi. Histopatoloji ve immünohistokimya lezyonun bir melanositom olduğunu gösterdi.

ANAHTAR SÖZCÜKLER: Melanositom, Foramen magnum, Kraniyovertebral bileşke

\section{INTRODUCTION}

Pigmented tumours of the central nervous system (CNS) are rare and range from a benign melanocytoma to an aggressive malignant melanoma $(1,2)$. Most commonly they are located over the posterior fossa and the cervical spinal cord. Spinal melanocytomas are also rare and their description is limited to case reports $(3,5,6,11)$. We report a case of a cervicomedullary junction melanocytoma and review the literature in brief.

\section{CASE SUMMARY}

A 55-year-old male presented with chief complaints of numbness and progressive weakness of all four limbs for the past one year, the left side more than right side. The patient was not a known diabetic or hypertensive. On examination, he had muscle atrophy, more in the thenar and hypothenar region, and the left more than the right side. He had motor power of grade $3 / 5$ on left side of body and $4 / 5$ on right side of body at all muscle groups. Tone was increased in all limbs. Deep tendon reflexes were exaggerated in all four limbs and bilateral plantars were extensors. The rest of the examination was within normal limits. The Magnetic Resonance Imaging (MRI) of the Craniovertebral Junction (CVJ) showed a welldefined lobulated intradural extramedullary mass lesion on the left side with extension to the left C2-3 neural foramina. The mass lesion was iso- to hyper-intense on $\mathrm{T} 1 \mathrm{~W}$ image, hypo-intense on $\mathrm{T} 2 \mathrm{~W}$ image and uniformly enhancing on intravenous gadolinium contrast (Figure $1 A-C$ ). The mass lesion was compressing and displacing the cord and lower medulla laterally towards the right side. There was mild widening of left C2-3 neural foramina. Few areas of hemorrhage were seen in extradural component of the lesion. The patient was operated in prone position through a foramen magnum approach with near total excision of tumor. On gross examination, there was black discoloration of dura. The tumor was intradural extramedullary, blackish grey, $3.5 \times 2 \mathrm{~cm}$ in size, encapsulated with moderate vascularity, and infiltrated the C1-2 intervertebral foramina on left side (Figure 2). The first and second cervical nerves on the left side were entrapped in tumor tissue. The patient improved after surgery with normal motor power $(5 / 5)$ on the right side of the body and left lower limb. The left upper limb power remained the same at 4-/5. The histopathology (HPE) showed a cellular tumour consisting of oval to spindle cells arranged in sheets, fascicles and whorled nests with round to oval nuclei, small nucleoli, few mitoses and moderately eosinophilic cytoplasm with indistinct margins. There was 

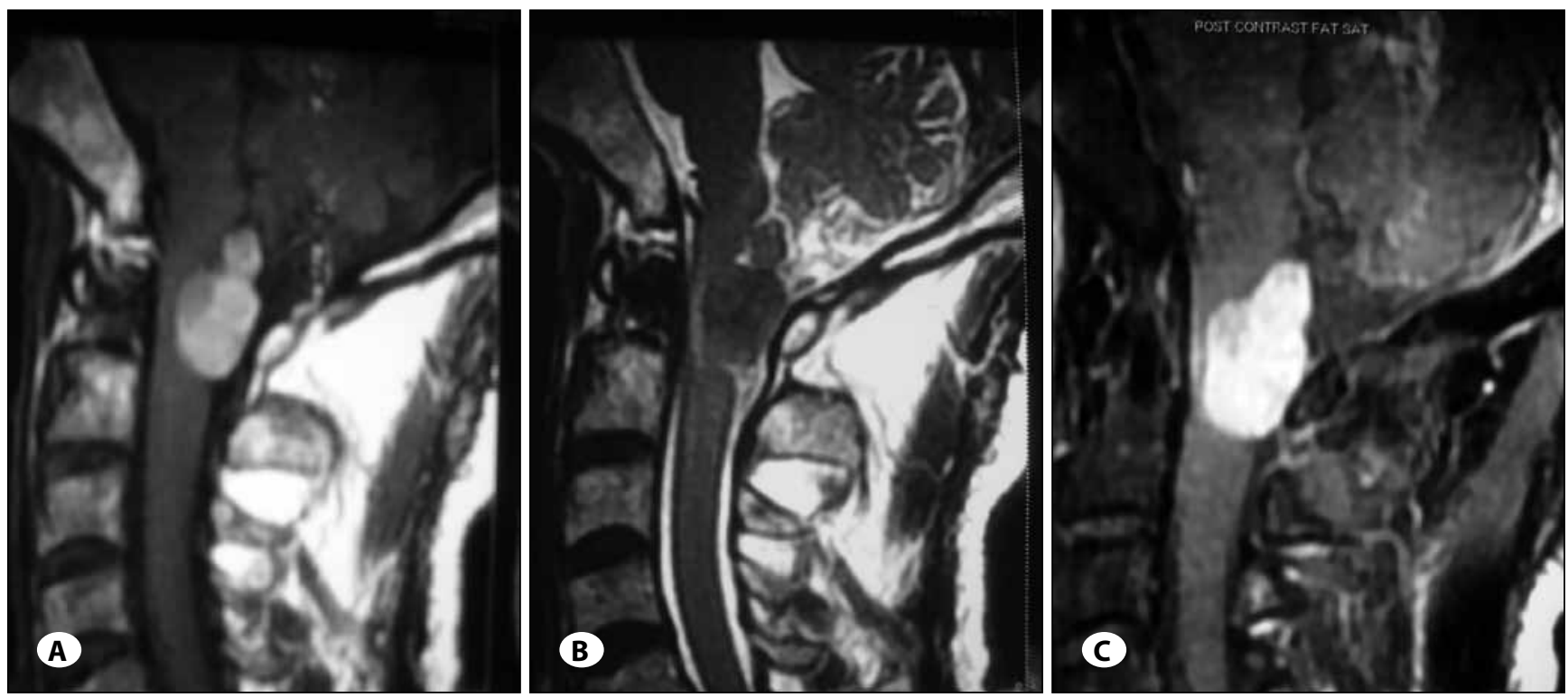

Figure 1: A) T1W MRI image. B) T2W MRI image. C) T1 contrast image.

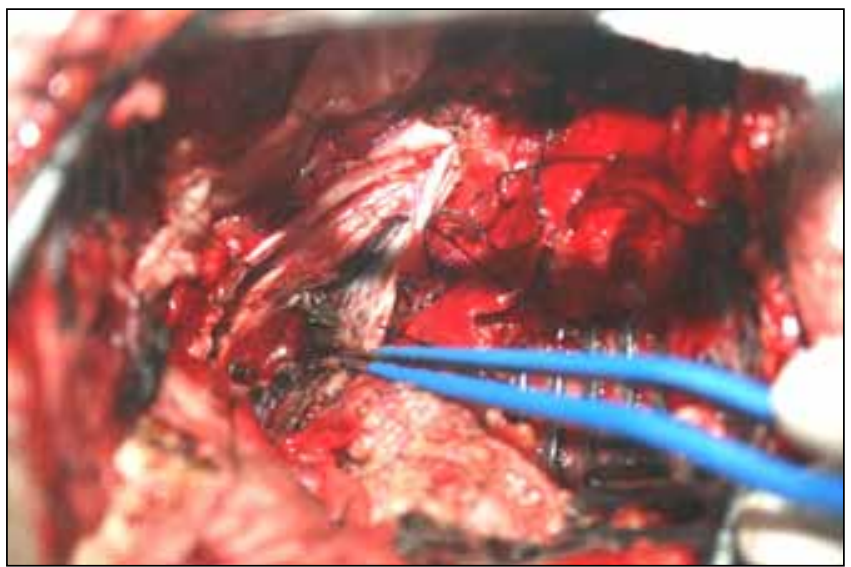

Figure 2: Intraoperative photograph showing blackish tumor.

abundant intracellular and extracellular melanin production. There were few haemorrhages but no necrosis was seen. Immunohistochemistry was positive for Human Melanoma Black (HMB) 45 and Vimentin and negative for NSE and GFAP (Figure 3A,B). The patient was advised Radiotherapy. At 1-year follow-up the patient was ambulatory but the power in the left upper limb did not improve.

\section{DISCUSSION}

The term melanocytoma was coined by Limas and Tio in 1972 (9). Primary melanocytic tumors of the central nervous system (CNS) are rare, constituting about $1 \%$ of all melanomas $(2,5,6)$. Spinal melanocytomas are even less frequent. In a series by Jaiswal et al only 2 of their 5 cases were in the spinal region, both present in the cervical region (6). They are more commonly seen in the fifth decade, more commonly in females. The most common location is the posterior fossa or over the cervical spinal cord (6).
The differential diagnosis for solitary pigmented lesions of the central nervous system includes melanocytoma, pigmented schwannomas, malignant melanoma, medulloblastoma or paraganglioma $(1,2)$. Melanocytomas are usually solitary, non invasive and relatively benign $(1,6)$. Spinal meningeal melanocytomas may be intradural or extradural. Clinically, spinal melanocytic tumors usually present with myeloradiculopathy. They arise from leptomeningeal melanocytes that are of neural crest origin $(5,6,10,11)$.

Grossly, melanocytomas are well-circumscribed, encapsulated, dark brown to black nodular tumors. They may be attached to the leptomeninges and micked by a meningioma with previous hemorrhage. Histologically, the cells are arranged in sheets of well-differentiated epitheloid cells, with round to oval nuclei and finely dispersed chromatin. There is abundance of intracytoplasmic melanin. Mitotic figures, hemorrhage and necrosis are usually not seen. Tight clustering of cells and prominent nucleoli may also be seen $(1,2,6,10,11)$.

Melanocytic tumors of the CNS may be classified as low grade (melanocytoma), intermediate grade, and high grade (melanoma) (1). A few authors consider melanocytomas a borderline tumor between cellular blue nevus and spindle melanoma (5).

Immunohistochemically, meningeal melanocytomas are positive for S100 protein, vimentin, and HMB45 antibody. Staining for keratin, epithelial membrane antigen (EMA), glial fibrillary acidic protein (GFAP), and neuron specific enolase (NSE) is negative. Ki 67 index is low indicating its benign nature $(2,5,8,9)$.

Our patient had well-circumscribed black coloured tumor. Microscopy showed a cellular tumor consisting of oval to spindle cells arranged in sheets, fascicles and whorled nests with round to oval nuclei, small nucleoli, few mitoses and 

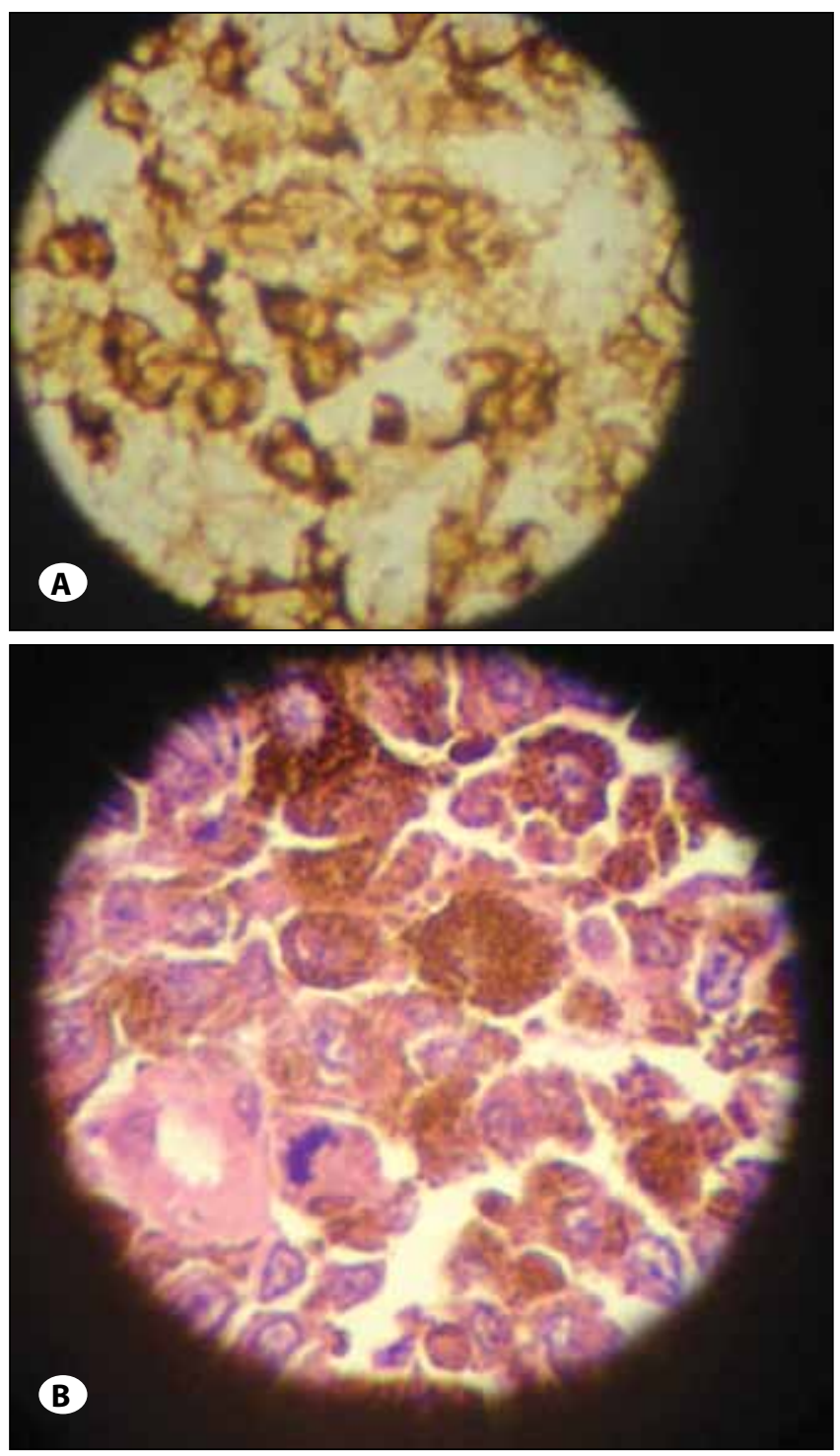

Figure 3A,B: HPE photomicrograph.

moderately eosinophilic cytoplasm with indistinct margins. There was abundant intracellular and extracellular melanin production. There were few haemorrhages but no necrosis was seen. Immunohistochemistry was positive for HMB 45 and Vimentin but negative for NSE and GFAP. These findings all suggested a melanocytoma.

Malignant melanomas which form the malignant spectrum histologically consist of spindled or epitheloid cells arranged in loose nests, fascicles, or sheets with variable cytoplasmic melanin pigment. Nuclear atypia, pleomorphism, anaplastic nuclei, mitosis and necrosis are features which favour a melanoma. Metastatic melanomas present as multiple lesions confined to CNS or other organs and have a poor prognosis $(5,6)$. Other conditions like primary leptomenengial melanosis also carry a poor prognosis.
The mainstay of treatment is surgical excision (5-11). A review of the literature on spinal meningeal melanocytoma shows that total resection was achieved in 8 of the 10 operated cases (10). A complete resection carries a better prognosis than incomplete resection $(4,7,10)$. A higher relapse rate is seen after incomplete resection (7). Primary high-dose radiotherapy has been shown to be effective in long-term control of the neoplasm in patients where no resection or incomplete resection (7). High doses of radiotherapy are requirements for optimal treatment of spinal meningeal melanocytoma, at least $50.4 \mathrm{~Gy}$ if $10 \mathrm{~cm}$ of the spinal cord requires radiation. It is suggested by Rades to give this dose of radiotherapy in 1.8 Gy fractions to reduce risk of myelopathy. This dose reduction to $48.6 \mathrm{~Gy}$ is preferable if $20 \mathrm{~cm}$ of cord requires irradiation (7). In most series, radiotherapy was not used after total resection (10). Rades et al suggest the use of radiotherapy even after complete resection to prevent recurrence (7).

Chemotherapeutic agents are used for malignant melanoma. Dacarbazine, cisplatin, carmustine, tamoxifen and fotemustine have all been tried in different combinations and regimes with varying results $(1,4)$. Fotemustine readily penetrates the blood brain barrier and has shown a response rate up to $28 \%$ in malignant melanoma but the confirmative role of chemotherapy in meningeal melanocytoma still requires further studies (4).

To conclude, spinal melanocytomas are rare. Their main differential is a melanoma which carries a worse prognosis, others being schwanomma, meningioma or a paraganglioma. Surgical excision forms the mainstay of treatment. Radiotherapy improves outcome after incomplete resection but its role after total resection is controversial.

\section{REFERENCES}

1. Brat DJ, Perry A: Melanocytic lesions. In: Louis DN, Ohgaki $\mathrm{H}$, Wiestler OD, Cavenee WK (eds), WHO Classification of Tumours of the Central Nervous System. 4th ed. Lyon: IARC Press, 2007:181-183

2. Brat DJ, Giannini C, Scheithauer BW, Burger PC: Primary melanocytic neoplasms of the central nervous system. Am J Surg Pathol 23:745-754, 1999

3. Clarke DB, Leblanc R, Bertrand G, Quartey GRC, Snipes GJ: Meningeal melanocytoma: Report of case and historical comparison. J Neurosurg 88:116-121,1998

4. Falkson $\mathrm{Cl}$, Falkson $\mathrm{G}$, Falkson $\mathrm{HC}$ : Phase II trial of fotemustine in patients with metastatic malignant melanoma. Invest New Drugs 12:251-254,1994

5. Ibanez J, Weil B, Ayala A, Jimenez A, Acedo C, Rodrigo I: Meningeal melanocytoma: Case report and review of the literature. Histopathology 30:576-581, 1997

6. Jaiswal S, Vij M, Tungria A, Jaiswal AK, Srivastava AK, Behari S: Primary melanocytic tumors of the central nervous system: A neuroradiological and clinicopathological study of 5 cases and brief review of literature. Neurology India 59(3): 413-419, 2011 
7. Rades D, Schild SE: Dose-response relationship for fractioned irradiation in the treatment of spinal meningeal melanocytoma: A review of the literature. Journal of NeuroOncology 77:311-314, 2006

8. Winston KR, Sotrel A, Schnitt SJ: Meningeal melanocytoma: Case report and review of clinical and histological features. J Neurosurg 66:50-57,1987

9. Limas C, Tio FO: Meningeal melanocytoma (melanotic meningioma). Its melanotic origin as revealed by electron microscopy. Cancer 30:1286-1294,1972
10. Sahin S, Simsek M, Yilmaz MS, Kir G, Naderi S: C4 nerve root meningeal melanocytoma: Confusing for spine surgeons? WSCJ 2: 37-41, 2011

11. Shanthi V, Ramakrishna BA, Bheemaraju VV, Rao NM, Athota VM: Spinal meningeal melanocytoma: $A$ rare meningeal tumor. Ann Indian Acad Neurol 13:308-310, 2010 